\title{
Entrepreneurial Intention in Advanced Undergraduate Students
}

\author{
Malefane Johannes Lebusa \\ Vaal University of Technology: Centre for Innovation \& Entrepreneurship \\ Email.johannesl@vut.ac.za/johannes.lebusa@gmail.com
}

\section{Doi:10.5901/mjss.2014.v5n27p760}

\begin{abstract}
This study was undertaken within a university that was historically designed to develop students for the intermediate level of the economy through replication of industrial processes. This was the main form of employment and accessing the economic activity. With unemployment rate amongst youth reportedly so high even in those with post-matric qualifications, the broadening of access to the economic activity has become urgent and relevant in undergraduate students. The reality is that until very recently with some few exceptions, the experience of the majority of the undergraduates was that they were effectively barred from meaningful access to entrepreneurial opportunities. There is a general contest that the current undergraduate programmes are orientating students as job-seekers and not job-creators. It is the assertion, therefore, of this study that Universities had to play a pivotal role in re-orientating undergraduates toward entrepreneurship. The study surveyed 210 undergraduates' students of Business Studies at a University of Technology to determine their degree of entrepreneurial intention. In this article, I share the results of the survey and attempt to map out a way forward for universities with respect to fostering entrepreneurship in undergraduate studies.
\end{abstract}

\section{Introduction and Problem Statement}

The level of unemployment in South Africa especially amongst the post-matric students is quite high (Bhorat, 2006). This is exacerbated by the country's slow rate of creating jobs despite enabling policies initiatives adopted by the government which revitalized the economy and eventually led to growth of 2.5\% a year. Unemployment rate has risen to around $40 \%$ if the numbers of those who have stopped looking for work is taken into account and has reached more than 50\% amongst youth between the ages of 18 to 35 years which includes those with post-school qualifications (Global Entrepreneurship Monitor, 2012). It is also reported that the country loses about 200000 to 300000 formal jobs per year (Bruggemans, 2009, Naong, 2011:181). This is also confirmed by the country's absorption rate of new recruits by the economy which has been dwindling from less than $4 \%$ from $64 \%$ (Davies, 2001:32) and there is scant evidence that suggests any improvement over the last decade. According to Anderson (2013), small business activity in South Africa is in a miserable state, entrepreneurship in the country is at its lowest level in three years, with dire implications for hopes of the sector creating thousands of new jobs.

The latest Global Entrepreneurship Monitor report found less than 14\% of South Africans surveyed planned to start a business within the next three years. It also found "total entrepreneurial activity" fell to $7.3 \%$ last year, from $9.1 \%$ in 2011 and $8.9 \%$ in 2010. To further highlight the challenge the country is facing, the Global Entrepreneurship Monitor $(G E M, 2008)$ and Mbeki (2009:97) painted a bleak picture of the South African Small Medium Macro Enterprises (SMMEs) sector' current potential to contribute meaningfully to job creation, economic growth and more equitable income distribution. The country's low levels of entrepreneurial activity are the result of environmental as well as personal factors with worrying trends such as drug abuse and unemployment, lack of access to technology and negative attitudes towards innovation leading to lack of entrepreneurial spirit.

This study is focused on how to encourage entrepreneurship among graduates. Graduate entrepreneurship around the globe is increasingly being seen as a vital source of competitiveness and the engine for economic growth and development. There is a strong global drive, towards encouraging a greater proportion of students to consider and pursue venture creation as an alternative career path for graduates (Nabi \& Holden, 2008:545). This study assumes that improving the skills base and fostering positive entrepreneurial attitudes through the education system are critical for economic growth. These entrepreneurship skills and techniques can be taught and have the potential to transform a good idea into a thriving enterprising business. According to Carvalho,Costa, Dominguishos and Pereira (2008:2), entrepreneurship skills can be developed and improved through students life, education system, particularly Higher Education Institutions, which assume an important role in teaching students to be entrepreneurial. It is assumed that this 
could contribute towards developing entrepreneurial behaviours which are vital for venture creation and enterprising behaviours (Nabi \& Holden, 2008:545). Education is more important than wealth in starting a business, and has helped people from modest backgrounds to establish some of the country's most successful companies (GEM, 2008 \& 2004). The country's youth (aged 15-24) since 1994 are becoming better educated, yet account for most of the growth in unemployment. Graduate unemployment has been growing fast since 1995 and most graduates with diploma struggle to secure employment. $82 \%$ of graduates with diplomas especially from University of Technologies are unemployed (Blaine, 2007). This paper investigated the entrepreneurial intentions of business management under-graduate students at a University of Technology in South Africa.

\section{Framing the Study}

This study uses an intention model, the Theory of Planned behaviour (TBP) as its theoretical framework as it attempts to determine the level of entrepreneurial intentions amongst under-graduate students. The study focuses on entrepreneurial intention because psychological attributes and personal characteristics have proven to be unreliable indicators of entrepreneurship; instead, intentions are the single best indicator of all planned behaviour (Krueger, Reilly \& Carsrud, 2000).

The TPB (Ajzen, 1997) identifies intentions as the direct antecedent of behaviour. According to Ajzen's TBP (19991:188), behaviour is determined by individual's intention to perform, or not to perform a given behaviour. According to Krueger, Reilly and Carsrud (2000:411), in psychological literature, intentions have proven the best predictor of planned behaviour, particularly when that behaviour is rare, hard to observe, or involves unpredictable time lags. New businesses emerge over time and involve considerable planning.

Dawkins and Frass (2005:513) posit that intention is determined by attitudes toward the behaviour: evaluation of the behaviour, subjective norms: perceived social pressure to perform or not to perform the behaviour and perceived behaviour control: the perceived degree of personal prerogative regarding the behavior. According to TPB, people will have strong intentions to perform a given action if they evaluate it positively, believe that important others would want them to perform it, and think that it is easy to perform (Sutton, 1998:1318). The intention to create a business is an important antecedent of actual effort to start a business. This theory indicates the effort that the students will make to carry out that entrepreneurial behaviour as they face the reality of high unemployment post-graduation.

Despite the recognition that education influence people attitudes towards starting their own business, the impact of entrepreneurship education, as distinct from general education, on attitudes or perceptions of entrepreneurship has remained relatively untested. In this paper, the Entrepreneurial Intention Model (fig.1) is used to frame the study.

Figure 1: Entrepreneurial Intention Model

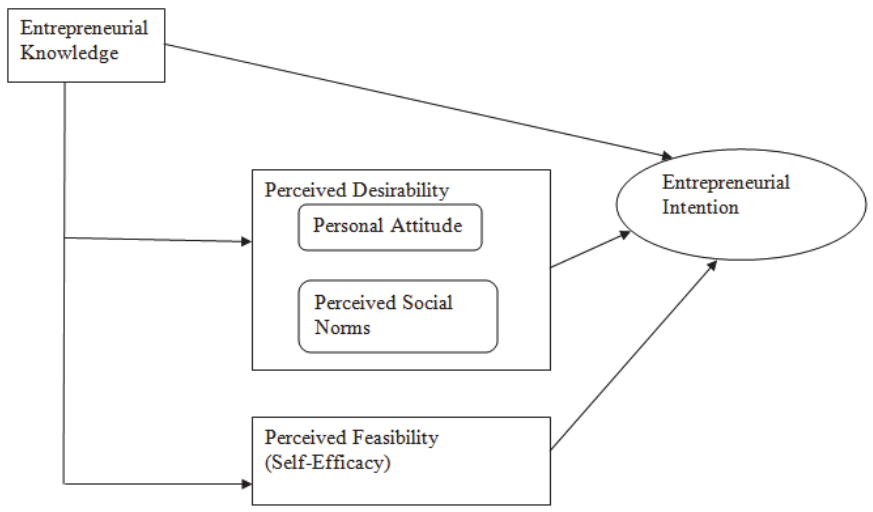

(Adopted from Shapero \& Sokol,1982; Ajzen,1991)

Krueger and Brazeal (1994:91) wrote that "before there can be entrepreneurship there must be the potential for entrepreneurship", indicating that the study of entrepreneurial intentions (potential) is vital in the endeavour to encourage entrepreneurial activity (Gird \& Bagraim, 2008:711). There is a growing body of literature arguing that intentions play a very relevant role in the decision to start a new business. Intentions capture the motivational factors which influence 
behaviour, the higher the intention to undertake the behaviour, the higher the probability of its performance will be (Linan \& Santos, 2007). According to Linan and Chen (2009:595), intention of carrying out entrepreneurial behaviours may be affected by several factors, such as needs, values, wants, habits, and beliefs. Krueger (1993:6) defined entrepreneurial intention as the commitment to performing behaviour that is necessary to physically start the business venture. Linan and Chen $(2009,596)$ identified the following three motivational factors, or antecedents, influencing entrepreneurial intention:

- Attitude toward start-up (personal attitude, PA): refers to the degree to which the individual holds a positive or negative personal valuation about being an entrepreneur. It includes not only affective (I like it, it is attractive), but also evaluative consideration (it has advantage)

- Subjective norm (SN): measures the perceived social pressure to carry out- or not to carry out- entrepreneurial behaviours. In particular, it would refer to the perception that "reference people" would approve of the decision to become an entrepreneur, or not.

- Perceived behavioural control (PBC): perception of the ease or difficulty of becoming and entrepreneur. This is similar quite similar to self-efficacy and perceived feasibility

For the purpose of this study, entrepreneurial intention will refer to the target behaviour of being self-employed or starting a business which has the variables of perceived desirability (personal attractiveness of being self-employed or starting a business), perceived feasibility (degree to which the individual feels capable starting a business) and social norms (social pressure to perform or not to perform entrepreneurial behaviour).

\section{Methodology}

\subsection{Participants}

Participants in this study consisted of 300 under-graduates students who are studying business management. They were surveyed and randomly selected for purpose of this study. It is the assumption of this paper that they are the appropriate participants to give us the entrepreneurial intention level that this study is hoping to determine because they are more likely than other students to embark on an entrepreneurial career. Of the 300 questionnaires distributed, only 210 were returned, yielding a response rate of $70 \%$.

\subsection{Research Instrument}

Information gathered from the literature study was used to develop and design a questionnaire to determine the students' level of entrepreneurial intention. This questionnaire was informed by the work developed of Krueger, Reilly and Carsrud (2000), Crant (1996) and Kickul and D' intino (2005). Questions attempts among others to find out what is the probability of these students starting their own business in the next five years, attractiveness of starting their own businesses and their belief in running a sustainable businesses.

\subsection{Procedure}

The survey was administered in person by the researcher. The participants completed a questionnaire for this study which was organized into two sections. The first section related to respondents' demographic characteristics. The second consists of items attempting to elicit respondents' entrepreneurial intention. A four point Likert-type scale was used where respondents had to indicate their responses as no intention, little intention, more intention and complete intention. The balanced four-point scale was chosen in order to eliminate the tendency of respondents to provide socially desirable responses so as to please the researcher or to appear helpful.

\section{Data Analysis}

All questionnaire items yielded a Cronbach Alpha coefficient of 0.914278 and average inter-item correlation of 0.267658 , which in consultation with the Statistical Services of the University was considered highly valid. The content validity was constructed by adhering to the three entrepreneurial intention constructs namely, attitude toward start-up (personal attitude, PA), subjective norm (SN) and perceived behavioural control (PBC). The entrepreneurial intention dimensions also yielded high Cronbach Apha coefficients, which was indicative of the high reliability, as illustrated in the table below: 


\begin{tabular}{|l|c|}
\hline Dimension & Cronbach Apha \\
\hline Attitude toward start-up (personal attitude, PA) & 0.964515 \\
\hline Subjective norm (SN) & 0.934625 \\
\hline Perceived behavioural control (PBC). & 0.913556 \\
\hline
\end{tabular}

\section{Results}

Findings from the descriptive data indicate general agreement with items relating to entrepreneurial intention as indicated by mean responses of $10.2(\mathrm{sd}=2.732)$ for personal attitude $(\mathrm{PA}), 6.65(\mathrm{sd}=2.223)$ for subjective norm $(\mathrm{SN})$ and 4.68 $(\mathrm{sd}=1.345)$ for perceived behavioural control $(\mathrm{PBC})$. Although this indicates a strong prospects of intention in students' intention in engaging in entrepreneurial activities, it is also evident the subjective norm perceived and perceived behavioural control does not enjoy practice as the other dimension of personal attitude. Items relating to personal attitude (PA) indicated that students are generally intent in engaging in entrepreneurial activities. When asked to respond to the statements "What is the probability you will start your own business in the next five years?"," How attractive an idea is starting your own business to you?", and "What is your value of starting your own business in terms of personal satisfaction?" , 64.4\%, 60.3\% and 59.8\% respectively showed intention.

A reasonable percentage of respondents on the question items relating to perceived behavioural control (PBC) have intention to be involved in entrepreneurial activities or new venture creation. When asked to respond to the statements "What is your perceived value of starting your own business in terms of autonomy?, "What is your perceive value of starting your own business in terms of stress?", and "What is your perceived value of starting your own business in terms of financial satisfaction?", $56.8 \%, 53.3 \%$ and $45.6 \%$ respectively showed above average intention to engaged in entrepreneurial activities and opening new venture. It was found, however, that below average percentage of the respondents did not show behavioural control in terms financial satisfaction.

It was found, however, that above average percentage of respondents show intent with the notions of subjective norm. On the questions "Rate the perceived reaction you could expect from friends to the subject of you starting your own business?", "Rate the perceived reaction you could expect from parents/family to the subject of you starting your own business?", "Rate the perceived reaction you could expect from mentor/role model to the subject of you starting a business?" and " Rate the perceived reaction you could expect from significant other to the subject of you starting your own business?", 54.2\%, 50.2\%, 58.6\% and 55.5\%.

\section{Limitations}

Two limitations are apparent in this study. First, the use of a cross-sectional design limits one's ability to capture changes in entrepreneurial intentions over time. As such, a longitudinal approach, which follows individual' student over time, is best for understanding the process of entrepreneurial intention, and future follow-up of respondents in the survey could shed more light on this subject.

Second, owing to the small size of the sample population $(n=210)$, inferences and assertions made in this article provides an indication of how entrepreneurship intention is among the students in this institution, without laying any claim to the generalisability of the results.

\section{Discussion and Conclusion}

Graduate entrepreneurship around the globe is increasingly being seen as a vital source of competitiveness and engine for economic growth and development (Nabi \& Holden, 2008:545). Institutions of higher learning are attempting very hard in producing an ever increasing number of graduates and government policy in many countries is seeking to promote self/small business employment as a viable career option in the wake of high loss of jobs by large firms as in the case in South Africa and any other countries. As emerging markets continue to be battered by the economic downturn, South Africa cannot rely on austerity-driven big business to resolve its unemployment crisis. Entrepreneurs are the only sustainable solution to creating real jobs

Higher Education Institution need to assist the country in creating an environment friendlier to small business and also encourages this sector. Supporting the fundamentals of entrepreneurship through courses they offer based on practical approach to facilitate entrepreneurship will go a long way in producing graduates relevant in assisting the country to redress high unemployment because training and education had a vital role to play in stoking entrepreneurship. In order to solve the youth unemployment challenge, we cannot rely on the large corporations to create 
sufficient amounts of jobs for the next generation. Instead, all stakeholders (policymakers, educators, large and small corporations and other support organizations) need to adapt and prepare the next generation to become job creators instead of job seekers.

Youth entrepreneurship must be considered a critical pathway to decent work for young people and has to form a strategic component of national efforts to address youth unemployment. The formalisation of a coherent entrepreneurship strategy would go a long way in determining where South Africa needs to be focusing and allocating scarce resources to offer co-ordinated support to entrepreneurs. The number of entrepreneurship programs has rapidly increased in the past years; however, little knowledge exists about their interconnection as well as their effectiveness. Finally, young aspiring entrepreneurs should see themselves as priceless, unique and passionate about their business ventures. With strategized mobilisation, mentorship, support and well-versed information to exploit opportunities, entrepreneurs can continue to be a driving force in today's modern economy. With South African Government's commitment to reducing red tape for small business owners and emphasis on gender equality, young entrepreneurs could look forward to breaking out the mindset that graduates are only good for selected professions.

\section{References}

Anderson, A. (2013) . Red tape 'killing' small business - Davies wants more. [online] Available from: http://www.bdlive.co.za/business/ 2013/04/24/red-tape-killing-small-business--davies-wants-more. [Accessed 25 April 2013]

Bhorat, H. (2006) . Unemployment in South Africa Descriptors and Determinants. Presentation to the Commission on Growth and Development, World Bank. Washington DC, October 15th 2006. School of Economics and Development Policy Research Unit, University of Cape Town

Blaine, S. (2007) . Most jobless graduates' hold diplomas. [online] Available from: http:// www.businessday.co.za/2007/03/05/news/ africa05asp. [Accessed 17 June 2009]

Bruggemans, C. (2009) . Zuma's ambitious vision for South Africa. Business Report 08 June:13

Carvalho,L, Costa, T, Dominguishos,P \& Pereira, R. (2008) . Entrepreneurship, methodologies in Higher Education: An experience in Portuguese Business School.[Web:]http://mpra.ub.uni-muenchen.de/12123. Access Date: 14/06/2009

Crant, J.M. (1996) . The proactive personality scale as a predicator of entrepreneurial intentions. Journal Small Business Management, $34,42-49$.

Dawkins, C.E. \& Frass, J.W. ( 2005) . Decision of union workers to participate in employee involvement: An application of the theory of planned behaviour. Employee Relations, 27(5):511-531.

Davidsonn. P. (1995) . Determinants of entrepreneurial intentions. Paper presented at the RENT IX Workshop. November 23-24, Piacenza, Italy.

Global Entrepreneurial Monitor (GEM). (2004). Global Entrepreneurship Monitor Report. Babson College, Kauffman Centre for Entrepreneurship. Boston, MA and London School of Economics, London.

Global Entrepreneurial Monitor (GEM). (2008). Global Entrepreneurship Monitor Report. Babson College, Kauffman Centre for Entrepreneurship. Boston, MA and London School of Economics, London.

Grid, A. \& Bagraim, J.J. (2008) . The theory of planned behaviour as predictor of entrepreneurial intent amongst final year university students. South African Journal of Psychology, 38 (4):711-724

Davies, T.A. (2001) . Entrepreneurship development in South Africa: redefining the role of tertiary institutions in a reconfigured higher education system. South African Journal of Higher Education, 15 (1): 32-9

Horwitz, F. (2007). The skills shortage: Myths and Realities? Paper presented at HRDA Conference, June 2007

Jansen, J. (2009). The answer lies in the hands of our youth-again. Sunday Star.20 June 2009

Kickul, J., \& D'Intino, R.S. (2005) . Measure for measure: modeling entrepreneurial self-efficacy onto instrumental tasks within the new venture creation process. New England Journal of Entrepreneurship, 8(2):39-47

Krueger, N.F. (1993) . The impact of prior entrepreneurial exposure on perceptions of new venture feasibility and desirability. Entrepreneurship Theory and Practice,18 (1): 5-23

Krueger Jr. ,N.F. \& Brazeal, D.V. (1994) . Entrepreneurial potential and potential entrepreneurs. Entrepreneurship Theory and Practice, 19, 91-94.

Krueger Jr., N.F.,Reilly, M.D. \& Carsrud, A.L. (2000) . Competing models of entrepreneurial intentions. Journal of Business Venturing,15, 411-432.

Li, W. (2006). Entrepreneurial Intention among international students: Testing a model of entrepreneurial intention. [Web:]http://usasbe.org/knowledge/proceedingsDocs/USAABE2006proceedings-Li\%20-\%Internet.pdf. Access date: 12/06/2009

Linan, F. \& Chen, Y. (2009). Development and Cross-Cultural Application of a Specific Instrument to measure Entrepreneurial Intentions. Entrepreneurship Theory and Practice, 33(3): 593-617.

Linan, F. \& Santos,F.J. (2007) . Does social capital affect entrepreneurial intentions? International Advances in Economic Research.

Mbeki, M. (2009) . Architects of Poverty: Why African capitalism needs changing. Pan Macmillan: South Africa

Mofokeng, M., Ndlangisa, S. \& Matlala, G. (2009) . JZ admits 500000 jobs flop.[Web:]www.citypress.co.za/2009/11/15/news/Africa. Access date: 17/11/2009 
Nabi, G. \& Holden, R. (2008) . Graduate entrepreneurship: intentions, education and training. Journal of Education \& Training, 50(7): 545-551.

Peterman, N.E \& Kennedy, J. (2003) . Enterprise Education: Influencing Students' Perceptions of Entrepreneurship. Entrepreneurship Theory and Practice,28 (2): 129-144.

Statistics South Africa. (2007). Statics South Africa, weekly newsletter, No 13.[Web]:http://www.statssa.gov.za.Acess Date:18/01/2008

Sutton, S. (1998) . Predicting and explaining intentions and behaviour: How well are we doing?.Journal of Applied Social Psychology, 28, 1317-1339.

The future will be tough. (2010). The Star Newspaper, 4 January: 8 